\title{
PENGARUH RASIO GEOMETRI ALUR PASAK POROS TERHADAP KEGAGALAN FATIGUE
}

\author{
Bachry Fahmiansyah, Sunardi, Erny Listijorini
}

Teknik Mesin, Fakultas Teknik, Universitas Sultan Ageng Tirtayasa

Jl. Jenderal Sudirman Km 3, Kotabumi, Kec. Purwakarta, Kota Cilegon, Banten, Indonesia

bachryfahmi19@gmail.com

\begin{abstract}
Abstrak
Fatigue merupakan salah satu penyebab kerusakan dari suatu poros. Kerusakan fatigue tidak dapat diprediksi, bisa terjadi secara tiba-tiba. Oleh karena itu perlu diteliti lebih lanjut tentang penyebab kegagalan fatigue. Pada penelitian sebelumnya sudah banyak yang melakukan improvement pada material yang biasa digunakan sebagai poros untuk meningkatkan kekuatan fatigue, tetapi masih sedikit penelitian yang membahas pengaruh kondisi permukaan pada poros terhadap kekuatan fatigue. Tujuan dari penelitian ini adalah untuk mengetahui pengaruh rasio geometri alur pasak poros terhadap kegagalan fatigue dengan melihat pada rasio kedalaman berapa material akan cepat patah. Metode yang digunakan adalah metode simulasi dengan software SolidWorks. Simulasi fatigue yang digunakan yaitu tipe rotary bending dengan standar pengujian ASTM E466. Varian rasio alur pasak yaitu 3:1 mm, 3:2 mm, dan 3:3 mm dengan masing-masing diberi beban 40\%, 50\%, $60 \%, 70 \%$, dan $80 \%$ dari ultimate tensile strength material. Hasil yang didapat pada beban $40 \%$ untuk varian 1,2,3 mencapai lebih dari 1.000 .000 siklus sampai patah. Pembebanan 50\% sama seperti pembebanan $40 \%$. Pembebanan $60 \%$ varian 1 masih mencapai 1.000 .000 siklus, sedangkan varian 2 mendapat 402.699 siklus, varian 3 mendapatkan 317.727 siklus sampai material patah. Pembebanan 70\% varian 1 mendapatkan 641211, varian 2 mendapatkan 201.348 siklus, varian 3 mendapatkan 166.116 siklus sampai material patah. Pembebanan $80 \%$ varian 1 mendapatkan 311.218 siklus, varian 2 mendapatkan 123.921 siklus, varian 3 mendapatkan 102.371 siklus sampai material patah. Dengan posisi patah yang sama pada setiap fillet alur pasak.
\end{abstract}

Kata kunci : Fatigue, Poros, Pasak, Simulasi, SolidWorks.

\begin{abstract}
Fatigue is one of the causes of damage for a shaft. Fatigue cannot be predicted, it can happen suddenly. Therefore need further improvement about fatigue causes. In previous studies, many researchers have made improvements for material commonly used as a shaft to increase the strength of fatigue, but there's still a little bit of research that discusses the surface design of the shaft. The purpose of this research is to study the effect of the ratio of the keyway geometry against fatigue by looking at the ratio between the width and depth of the keyway. The method is a simulation method with SolidWorks. The fatigue simulation typed use is rotary bending with ASTM E466 standard. The keyway ratio variants are 3:1 mm, 3:2 $\mathrm{mm}$, and 3:3 $\mathrm{mm}$ with each load are 40\%, 50\%, 60\%, 70\%, and 80\% from ultimate tensile strength material. The results in a 40\% load, variants 1,2,3 reach more than 1.000 .000 cycles until broken. 50\% loading as the same as $40 \%$ loading. Until $60 \%$ load, variant 1 still reaches 1.000 .000 cycles, variant 2 gets 402.699 cycles, variant 3 gets 317.727 cycles until the material is damaged. $70 \%$ load, variant 1 gets 641.211 cycles, variant 2 gets 201348 cycles, variant 3 gets 166.116 cycles until the material is damaged. 80\% load, variant 1 gets 311.218 cycles, variant 2 gets 123.921 cycles, variant 3 gets 102.371 cycles until the material is damaged. With the same broken position on each round groove keyway.
\end{abstract}

Key words : Fatigue, Shaft, Key, Simulation, SolidWorks

8 Fahmiansyah, Bachry., dkk; Pengaruh Rasio Geometri Alur Pasak Poros Terhadap Kegagalan Fatigue 


\section{PENDAHULUAN}

Fatigue atau kelelahan adalah kerusakan material yang diakibatkan oleh adanya tegangan yang berfluktuasi yang besarnya lebih kecil dari tegangan tarik maksimum (ultimate tensile strength) $(\sigma \mathrm{u})$ maupun tegangan luluh (yield) material yang diberikan beban konstan. Resistensi kelelahan (fatigue) adalah kemampuan material untuk menerima pebebanan berulang dan berfluktuasi selama periode tertentu sampai material mengalami perpatahan [1]. Terdapat tiga fase dalam perpatahan fatik yaitu permulaan retak, penyebaran retak, dan patah. Salah satu komponen mesin yang dapat mengalami fatigue adalah poros. Poros digunakan untuk meneruskan putaran atau mentransmisikan putaran dari penggerak dan kepada yang digerakkan. Dalam menjalankan tugasnya sebagai sumbu putar, poros memiliki alur pasak untuk tempat diselipkannya pasak yang digunakan untuk kuncian dari poros terhadap puli atau semacamnya. Pasak merupakan sepotong baja lunak (mild steel) yang berfungsi sebagai pengunci yang disisipkan diantara poros dan $h u b$ (bos) sebuah roda puli atau roda gigi agar keduanya tersambung dengan pasti sehingga mampu meneruskan momen putar/torsi.

Komponen mesin yang memiliki konsentrasi tegangan akan berpengaruh terhadap performanya. Sunardi et.al [2] melakukan riset tentang bentuk-bentuk konsentrasi tegangan terhadap perubahan kekuatan, kekakuan dan getaran balok. Dari riset ini diketahui bahwa konsentrasi tegangan berbentuk balok memiliki performa yang paling baik jika dibandingkan dengan bentuk lainnya. Jarak antara konsentrasi tegangan juga berpengaruh sangat signifikan terhadap perubahan kinerja balok. Dari riset ini diketahui bahwa semakin dekat jarak antar titik-titik konsentrasi tegangan maka akan semakin besar tegangan, defleksi dan getaran yang terjadi pada balok [3].

Model elemen hingga dari sampel pengujian fatigue dari bahan baja berkekuatan tinggi Weldox 960 dibuat dalam program ADINA. Model bahan simulasi sesuai dengan bahan nyata yang digunakan dan didasarkan pada uji tariknya. Pembebanan sampel diterapkan dalam bentuk sudut rotasi (sesuai dengan torsi siklik) dan serangkaian simulasi untuk setiap level pembebanan dilakukan. Nilai tegangan dan regangan diperoleh untuk setiap level beban dan menjadi dasar untuk pengukuran eksperimental fatigue pada sampel nyata [4]. Pengujian fatigue dilakukan dengan cara memberikan stress level tertentu sehingga spesimen patah pada siklus tertentu [5].

Material bronze diuji dengan mesin rotary bending untuk mengetahui kekuatan fatigue dari material tersebut. Bronze diuji sebanyak 5 kali dengan pembebanan $10 \mathrm{~kg}, 15 \mathrm{~kg}, 20 \mathrm{~kg}, 25 \mathrm{~kg}$, dan $30 \mathrm{~kg}$. dari hasil penelitian ini akan terlihat hasil bahwa ketahanan fatigue dari material bronze akan menurun seiring dengan bertambahnya beban yang diberikan dan siklus putaran akan semakin sedikit. Fatigue sangat berbahaya dibanding kegagalan statis karena fatigue terjadi tanpa ada peringatan terlebih dahulu atau secara tiba tiba dan menyeluruh [6]. Oleh sebab itu pengujian fatigue sangat perlu dilakukan pada sebuah material untuk mengetahui ketangguhan dari sebuah material.

Pasak dan alur pasak adalah salah satu koneksi poros- $h u b$ yang paling umum. Desain sering diatur oleh standar yang hampir setengah abad, dan sebagian besar hasil yang dilaporkan dalam literatur didasarkan pada analisis fotoelastik eksperimental. Makalah ini menunjukkan bagaimana analisis elemen hingga numerik dapat meningkatkan prediksi konsentrasi tegangan di alur pasak. Dengan menggunakan pengoptimalan bentuk dan bentuk super elips sederhana, ditunjukkan bahwa usia kelelahan alur pasak dapat sangat ditingkatkan dengan pengurangan hingga $50 \%$ pada tegangan maksimum [7]. Hal ini menunujukkan bahwa bentuk alur pasak sangat mempengaruhi kekuatan fatigue material.

Isranuri et.al [8] Memodifikasi material dengan mencampurkan $96 \%$ alumunium dan $4 \%$ magnesium, kemudian material tersebut diuji kekuatan fatigue nya dan membandingkan hasil uji fatigue sebenarnya dengan hasil uji fatigue dengan simulasi. Jenis uji fatigue nya adalah rotary bending. Simulasi ini menggunakan software ANSYS dan diapatkan hasil beban $117,13 \mathrm{~N}$ dengan siklus 47.120, beban 74,752 $\mathrm{N}$ dengan siklus 82.565 , beban $58,5657 \mathrm{~N}$ dengan siklus 135.515. Faktor kunci dalam analisis elemen hingga adalah perhitungan numerik dengan maksud memperkirakan semua parameter dan batas yang disepakati [9]. Analisis kegagalan adalah sesuatu yang sangat diperlukan yang digunakan secara luas oleh sektor industri untuk mengembangkan atau meningkatkan desain produk. Kegagalan elemen mesin dipelajari secara luas oleh ilmuwan untuk menemukan metode untuk mengidentifikasi penyebabnya dan untuk mencegahnya terulang kembali. Untuk menentukan mode kegagalan, metode analisis elemen analitik, eksperimental, dan elemen hingga dapat digunakan [10].

Fillet pada poros membawa zona tegangan dari daerah yang dilalui seperti alur pasak dan lubang ke bentuk. Garis-garis gaya yang berubah pada titik ini dan mengubah arah ketajamannya dibulatkan untuk mencoba mengurangi efek takik yang terjadi pada gaya dinamis dan dalam bahan yang ringkih. [11]. Kelelahan logam adalah masalah yang signifikan karena dapat terjadi karena beban

9 Fahmiansyah, Bachry., dkk; Pengaruh Rasio Geometri Alur Pasak Poros Terhadap Kegagalan Fatigue 
berulang di bawah kekuatan luluh statis. Hal ini dapat mengakibatkan kegagalan yang tidak terduga dan bencana dalam penggunaan karena sebagian besar bahan teknik mengandung diskontinuitas. Sebagian besar retakan fatik berawal dari diskontinuitas di daerah komponen yang sangat tertekan. Kegagalan mungkin disebabkan oleh diskontinuitas, desain, perawatan yang tidak tepat atau penyebab lainnya. Analisis kegagalan dapat menentukan penyebab kegagalan [12]. Kegagalan fatigue dimulai dengan terjadinya retakan pada permukaan benda uji. Hal ini membuktikan bahwa sifat - sifat fatigue sangat peka terhadap kondisi permukaan, yang dipengaruhi oleh beberapa faktor antara lain kekasaran permukaan, perubahan sifat sifat permukaan dan tegangan sisa permukaan [13].

Penelitian ini bertujuan untuk meneliti pada setiap rasio geometri alur pasak poros, yaitu rasio antara lebar pasak dengan kedalaman pasak terhadap kelelahannya (fatigue) pada material baja AISI 410. Untuk melihat apakah alur pasak dapat menjadi pemicu adanya permulaan retak pada poros. Serta apakah kedalaman alur pasaka berpengaruh besar terhadap kegagalan fatigue.

\section{METODE PENELITIAN}

\section{Material}

Bahan yang digunakan pada simulasi pengujian ini adalah baja AISI 410. Baja AISI (American Iron and Steel Institute) 410 termasuk ke dalam stainless steel atau baja tahan karat. Dalam SAE International (Society of Automotive Engineers), baja ini juga bernomor 410 karena AISI dan SAE keduanya terlibat dalam upaya untuk membakukan penomoran baja. Kemudian di dalam UNS (Unified Numbering System) baja ini bernomor S41000. Baja AISI 410 termasuk ke dalam stainless steel seri 400 yaitu ferritic and martensitic chromium alloys, dan tipe 410 ini termasuk ke dalam martensitic (high - strength iron / chromium) mempunyai kekuatan aus yang tinggi tetapi ketahanan korosi yang kurang hingga cukup [14]. Karena baja AISI 410 ini mempunyai ketahanan aus yang tinggi, material ini cocok digunakan untuk poros.

Tabel 1 Komposisi Baja AISI 410

\begin{tabular}{lccccccc}
\hline & $\mathrm{C}$ & $\mathrm{Cr}$ & $\mathrm{P}$ & $\mathrm{S}$ & $\mathrm{Ni}$ & $\mathrm{M}$ & $\mathrm{S}$ \\
& & & & & & $\mathrm{n}$ & $\mathrm{i}$ \\
\hline Min & - & $\mathbf{1 1 . 5}$ & - & - & $\mathbf{0 .}$ & - & - \\
\cline { 1 - 5 } & $\mathbf{0 . 1 5}$ & $\mathbf{1 3 . 5}$ & $\mathbf{0 . 0 4}$ & $\mathbf{0 . 0 3}$ & $\mathbf{7 5}$ & $\mathbf{1}$ & $\mathbf{1}$ \\
\hline
\end{tabular}

Sumber : www.azom.com
Tabel 2 Mechanical Properties of AISI 410 Steel

\begin{tabular}{lll}
\hline \multicolumn{1}{c}{ Properties } & \multicolumn{1}{c}{ Value } & \multicolumn{1}{c}{ Unit } \\
\hline Elastic Modulus & $\mathbf{2 0 0}$ & GPa \\
\hline Poisson's Ratio & $\mathbf{0 . 2 8}$ & \\
\hline Shear Modulus & $\mathbf{7 7 . 5 2}$ & $\mathbf{G P a}$ \\
\hline Mass Density & $\mathbf{7 7 4 0}$ & $\mathbf{K g} / \mathbf{m 3}$ \\
\hline Tensile Strength & $\mathbf{5 1 0}$ & $\mathbf{M P a}$ \\
\hline Yield Strength & $\mathbf{3 1 0}$ & $\mathrm{MPa}$ \\
\hline $\begin{array}{l}\text { Thermal Expansion } \\
\text { Coefficient }\end{array}$ & $\mathbf{9 . 9}$ & $/ \mathrm{K}$ \\
\hline $\begin{array}{l}\text { Thermal } \\
\text { Conductivity }\end{array}$ & $\mathbf{1 8 . 3}$ & $\mathrm{W} /(\mathbf{m} . \mathbf{K})$ \\
\hline Specific Heat & $\mathbf{4 6 0}$ & $\mathrm{J} /(\mathbf{K g} . \mathbf{K})$ \\
\hline
\end{tabular}

\section{Metode}

Metode pengujian menggunakan metode simulasi, yaitu mensimulasikan pengujian fatigue dengan menggunakan software SolidWorks. Pada metode simulasi material dibentuk dengan software SolidWorks mengacu pada dimensi standar ASTM E466 yang mana standar ini juga biasa digunakan pada uji fatigue tipe rotary bending. Kemudian simulasi pengujian material dilakukan juga dengan software SolidWorks menggunakan pembebanan statis dan fatigue untuk mendapatkan hasil yang mendekati dengan pengujian real di lapangan. Kemudian untuk pembebanan material diberikan beban $40 \%, 50 \%, 60 \%$, 70\%, dan $80 \%$ dari ultimate tensile strength material

\section{Standar Pengujian}

Standar untuk pengujian rotary bending menggunakan ASTM E466 dengan variasi kedalaman celah $1 \mathrm{~mm}, 2 \mathrm{~mm}$, dan $3 \mathrm{~mm}$. Sedangkan untuk lebar dan panjang di setiap variasi adalah sama yaitu $3 \mathrm{~mm}$ x $14 \mathrm{~mm}$.

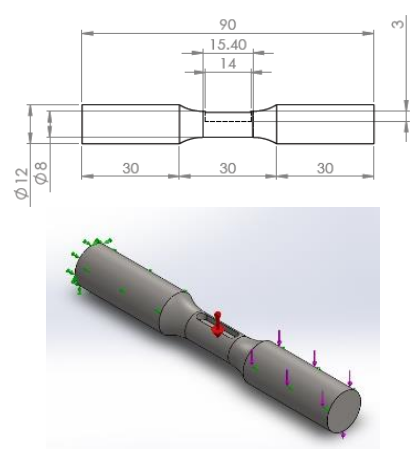

\section{Gambar 1 Standar ASTM E466}

Tumpuan dan beban pada material dibuat agar sama persis dengan kondisi real pengujian. Untuk tumpuan menggunakan tumpuan roll dan fix karena untuk pengujian fatigue akan menggunakan jenis rotary bending. Untuk tumpuan roll

10 Fahmiansyah, Bachry., dkk; Pengaruh Rasio Geometri Alur Pasak Poros Terhadap Kegagalan Fatigue 
ditunjukkan pada gambar 1 dengan anak panah hijau kecil yang mengarah ke kiri, sedangkan untuk tumpuan fix terletak pada penampang kiri spesimen. Untuk beban ditunjukkan oleh panah ungu yang mengarah kebawah, beban diberikan pada tempat yang serupa mungkin dengan pengujian experimental. Kemudian untuk beban gravitasi ditunjukkan oleh panah merah besar mengarah kebawah.

Pengujian fatigue dilakukan dengan simulasi tipe rotary bending. Jika benda uji diputar dan diberi beban, maka akan terjadi momen lentur pada benda uji. Momen lentur ini menyebabkan terjadinya beban lentur pada benda uji. Momen lentur ini menyebabkan terjadinya beban lentur pada permukaan benda uji dan besarnya dihitung dengan persamaan [5].

$$
\sigma=\frac{w \times l / 2}{\pi / 32 \times d^{3}} \mathrm{~kg} / \mathrm{cm}^{2}
$$

$\sigma=$ Tegangan tarik $\left(\mathrm{kg} / \mathrm{cm}^{2}\right)$

$\mathrm{w}=$ Beban lentur $(\mathrm{kg})$

$\mathrm{d}=$ Diameter benda uji $(\mathrm{cm})$

$l=$ Panjang benda uji $(\mathrm{cm})$

Penyajian data fatigue rekayasa adalah menggunakan kurva S-N yaitu pemetaan tegangan (S) terhadap jumlah siklus sampai terjadi kegagalan (N). Kurva S-N ini lebih diutamakan menggunakan skala semi log. Kurva tersebut didapat dari pemetaan tegangan terhadap jumlah siklus sampai terjadi kegagalan pada benda uji. Pada kurva ini siklus menggunakan skala logaritma. Batas ketahan fatigue (endurance limit) baja ditentukan pada jumlah siklus $\mathrm{N}>107$ [15].

Pengujian fatigue dilakukan dengan cara memberikan stress level tertentu sehingga spesimen patah pada siklus tertentu. [15] Menyatakan untuk mendapatkan kurva S-N dibutuhkan 8-12 spesimen. Retak fatigue biasanya dimulai pada permukaan di mana lentur dan torsi menyebabkan terjadinya tegangan-tegangan yang tinggi atau di tempattempat yang tidak rata menyebabkan terjadinya konsentrasi tegangan. Oleh karena itu, batas ketahanan (endurance limit) sangat tergantung pada kualitas penyelesaian permukaan [16].

\section{HASIL DAN PEMBAHASAN}

Merujuk pada persamaan (1), maka hasil perhitungan beban untuk beban $40 \%, 50 \%, 60 \%$, $70 \%$, dan $80 \%$ secara berturut-turut adalah sebagai berikut:

Tabel 3 Variasi Nilai Beban

\begin{tabular}{cccc}
\hline $\begin{array}{c}\text { UTS } \\
(\mathrm{MPa})\end{array}$ & $\begin{array}{c}\text { Variasi } \\
\text { Pembebanan }(\%)\end{array}$ & $\begin{array}{c}\sigma \\
(\mathrm{MPa})\end{array}$ & w $(\mathrm{N})$ \\
\hline $\mathbf{5 1 0}$ & $\mathbf{4 0}$ & $\mathbf{2 0 4}$ & $\mathbf{2 2 7 , 7 6}$ \\
\hline
\end{tabular}

\begin{tabular}{cccc}
\hline \multirow{2}{*}{$\begin{array}{c}\text { UTS } \\
(\mathrm{MPa})\end{array}$} & $\begin{array}{c}\text { Variasi } \\
\text { Pembebanan }(\%)\end{array}$ & $\begin{array}{c}\sigma \\
(\mathrm{MPa})\end{array}$ & w $(\mathrm{N})$ \\
\hline & $\mathbf{5 0}$ & $\mathbf{2 5 5}$ & $\mathbf{2 8 4 , 6 9}$ \\
\cline { 2 - 4 } & $\mathbf{6 0}$ & $\mathbf{3 0 6}$ & $\mathbf{3 4 1 , 6 3 2}$ \\
\cline { 2 - 4 } & $\mathbf{7 0}$ & $\mathbf{3 5 7}$ & $\mathbf{3 9 8 , 5 7 1}$ \\
\cline { 2 - 4 } & $\mathbf{8 0}$ & $\mathbf{4 0 8}$ & $\mathbf{4 5 5 , 5 0 9}$ \\
\hline
\end{tabular}

Setelah menghitung beban yang akan diberikan saat simulasi, selanjutnya adalah melakukan simulasi uji statis dengan memasukkan variasi pembebanan pada setiap variasi rasio alur pasak. Setelah melakukan simulasi uji statis maka akan didapatkan nilai deformation. Spesimen yang sudah melakukan simulasi uji statis selanjutnya melakukan simulasi uji fatigue untuk mendapatkan nilai life dan safety factor dari spesimen uji ASTM E466 dengan variasi rasio alur pasak. Berikut ini adalah hasil dari simulasi pengujian statis dan fatigue:

Tabel 4 Hasil Simulasi Rasio Alur 3:1

\begin{tabular}{cccccc}
\hline \multirow{2}{*}{ Keterangan } & \multicolumn{5}{c}{ Variasi Rasio Alur Pasak } \\
\cline { 2 - 6 } Beban (\%) & $\mathbf{4 0}$ & $\mathbf{5 0}$ & $\mathbf{6 0}$ & $\mathbf{7 0}$ & $\mathbf{8 0}$ \\
\hline $\boldsymbol{\sigma}(\mathrm{MPa})$ & $\mathbf{2 0 4}$ & $\mathbf{2 5 5}$ & $\mathbf{3 0 6}$ & $\mathbf{3 5 7}$ & $\mathbf{4 0 8}$ \\
\hline $\begin{array}{c}\text { Deformasi } \\
(\mathbf{m m})\end{array}$ & $\begin{array}{c}\mathbf{0 , 0 1} \\
\mathbf{2}\end{array}$ & $\begin{array}{c}\mathbf{0 , 0 1} \\
\mathbf{5}\end{array}$ & $\begin{array}{c}\mathbf{0 , 0 1} \\
\mathbf{8}\end{array}$ & $\begin{array}{c}\mathbf{1} 02 \\
\mathbf{0 , 0}\end{array}$ & $\mathbf{2 4}$ \\
\hline Siklus & $\mathbf{1 e 0 6}$ & $\mathbf{1 e 0 6}$ & $\mathbf{1 e 0 6}$ & $\begin{array}{c}\mathbf{6 4 1} \\
\mathbf{2 1 1}\end{array}$ & $\begin{array}{c}\mathbf{3 1 1} \\
\mathbf{2 1 8}\end{array}$ \\
\hline $\begin{array}{c}\text { Safety } \\
\text { Factor }\end{array}$ & $\mathbf{1 , 6 6}$ & $\mathbf{1 , 3 3}$ & $\mathbf{1 , 1 1}$ & $\mathbf{0 , 9 5}$ & $\mathbf{0 , 8}$ \\
\hline
\end{tabular}

Tabel 5 Hasil Simulasi Rasio Alur 3:2

\begin{tabular}{cccccc}
\hline \multirow{2}{*}{ Keterangan } & \multicolumn{5}{c}{ Variasi Rasio Alur Pasak } \\
\cline { 2 - 6 } Beban (\%) & $\mathbf{4 0}$ & $\mathbf{5 0}$ & $\mathbf{6 0}$ & $\mathbf{7 0}$ & $\mathbf{8 0}$ \\
\hline $\boldsymbol{\sigma}(\mathbf{M P a})$ & $\mathbf{2 0 4}$ & $\mathbf{2 5 5}$ & $\mathbf{3 0 6}$ & $\mathbf{3 5 7}$ & $\mathbf{4 0 8}$ \\
\hline $\begin{array}{c}\text { Deformasi } \\
(\mathbf{m m})\end{array}$ & $\mathbf{0 , 0 1}$ & $\mathbf{0 , 0 1}$ & $\mathbf{0 , 0 1}$ & $\mathbf{0 , 0 2}$ & $\mathbf{0 , 0}$ \\
\hline Siklus & $\mathbf{1 e 0 6}$ & $\mathbf{1 e 0 6}$ & $\begin{array}{c}\mathbf{4 0 2} . \\
\mathbf{6 9 9}\end{array}$ & $\mathbf{2 0 1 .}$ & $\mathbf{1 2 3}$ \\
\hline $\begin{array}{c}\text { Safety } \\
\text { Factor }\end{array}$ & $\mathbf{1 , 3 2}$ & $\mathbf{1 , 0 6}$ & $\mathbf{0 , 8 8}$ & $\mathbf{0 , 7 6}$ & $\begin{array}{c}\mathbf{0 , 6} \\
\mathbf{6}\end{array}$ \\
\hline
\end{tabular}

Tabel 6 Hasil Simulasi Rasio Alur 3:3

\begin{tabular}{cccccc}
\hline \multirow{2}{*}{ Keterangan } & \multicolumn{5}{c}{ Variasi Rasio Alur Pasak } \\
\cline { 2 - 6 } & \multicolumn{5}{c}{$3: 1 \mathrm{~mm}$} \\
\hline Beban (\%) & $\mathbf{4 0}$ & $\mathbf{5 0}$ & $\mathbf{6 0}$ & $\mathbf{7 0}$ & $\mathbf{8 0}$ \\
\hline $\boldsymbol{\sigma}(\mathrm{MPa})$ & $\mathbf{2 0 4}$ & $\mathbf{2 5 5}$ & $\mathbf{3 0 6}$ & $\mathbf{3 5 7}$ & $\mathbf{4 0 8}$ \\
\hline $\begin{array}{c}\text { Deformasi } \\
\text { (mm) }\end{array}$ & $\mathbf{0 , 0 1}$ & $\mathbf{0 , 0 1}$ & $\mathbf{0 , 0 1}$ & $\mathbf{0 , 0 2}$ & $\mathbf{0 , 0}$ \\
\hline Siklus & $\mathbf{1 e 0 6}$ & $\mathbf{1 e 0 6}$ & $\mathbf{3 1 7}$ & $\mathbf{1 6 6}$ & $\mathbf{1 0 2}$ \\
& & & $\mathbf{7 2 7}$ & $\mathbf{1 1 6}$ & $\mathbf{3 7 1}$ \\
\hline
\end{tabular}

11 Fahmiansyah, Bachry., dkk; Pengaruh Rasio Geometri Alur Pasak Poros Terhadap Kegagalan Fatigue 


\begin{tabular}{llllll}
\hline $\begin{array}{l}\text { Safety } \\
\text { Factor }\end{array}$ & 1,25 & 1,00 & 0,84 & 0,72 & $\begin{array}{c}0,6 \\
3\end{array}$ \\
\hline
\end{tabular}

Dari hasil pengujian yang terdapat pada tabel 4, 5 dan 6 masing - masing memiliki nilai yang berbeda, semakin dalam kedalaman alur dan semakin besar pembebanannya maka umur material akan semakin pendek dilihat dari minimum siklus yang di dapat. Nilai siklus minimal tertinggi terdapat pada simulasi fatigue dengan variasi rasio alur pasak 3:1 yaitu mencapai 1.000.000 siklus sedangkan nilai siklus minimal terendah terdapat pada rasio alur pasak 3:3 yaitu 102.371 siklus.

Kemudian dari tabel di atas dapat kita lihat bahwa terdapat 3 varian pengujian yaitu $3: 1 \mathrm{~mm}, 3: 2$ $\mathrm{mm}$, dan $3: 3 \mathrm{~mm}$ dengan 5 variasi pembebanan.

Untuk varian 1, 2, dan 3 pada pembebanan $204 \mathrm{MPa}$ dan $255 \mathrm{MPa}$ dapat mencapai di atas 1.000.000 siklus sampai material patah. Hingga pembebanan $306 \mathrm{MPa}$ untuk varian 1 masih bisa mencapai 1.000.000 siklus, sedangkan varian 2 hanya dapat mencapai 402.699 dan varian 3 hanya mencapai 317.727 siklus sampai material patah. Kemudian pada pembebanan $357 \mathrm{MPa}$ untuk varian 1 mendapatkan 641.211 siklus, varian 2 mendapatkan 201.348 siklus, dan varian 3 mendapatkan 166.116 siklus sampai material patah. Pada variasi pembebanan terakhir yaitu $408 \mathrm{MPa}$ untuk varian 1 mendapatkan 311.218 siklus, varian 2 mendapatkan 123.921, sedangkan varian 3 mendapatkan 102.371 siklus sampai material patah.

Dari tabel 4, 5, 6 juga dapat dilihat nilai safety factor dari setiap hasil simulasi. Untuk hasil simulasi yang memiliki nilai safety factor di bawah 1, maka dari hasil simulasi tersebut dapat mengindikasikan pada konsisi real pengujian dengan beban yang diberikan sama, material akan mengalami kerusakan sebelum 1.000.000 siklus. Namun jika nilai safety factor masih di atas atau sama dengan 1 maka pada kondisi real pengujian material masih dinyatakan aman dan tidak mengalami kerusakan sampai 1.000 .000 siklus [17].

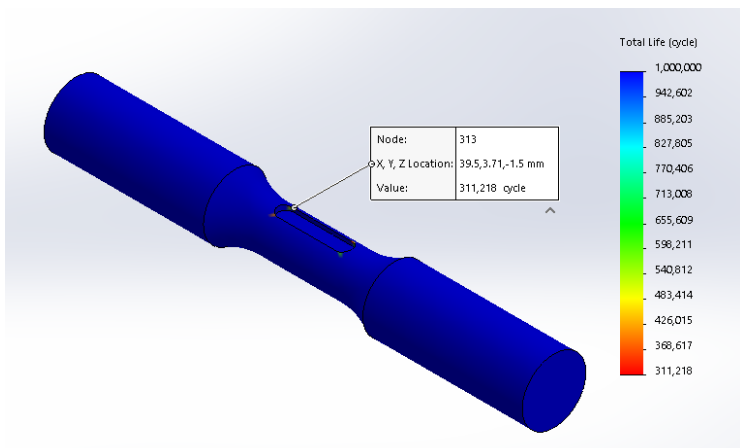

Gambar 2 Simulasi Uji Fatigue Rasio Alur Pasak 3:1

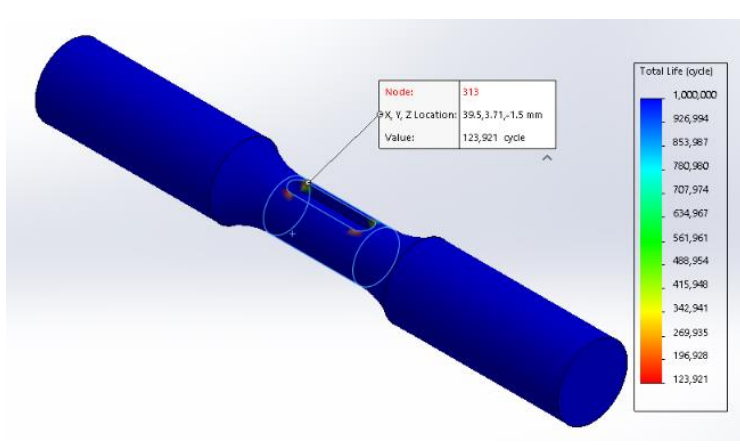

\section{Gambar 3 Simulasi Uji Fatigue Rasio Alur Pasak 3:2}

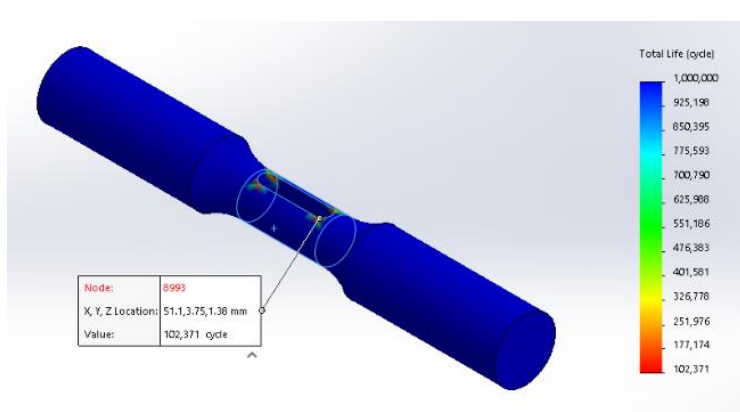

\section{Gambar 4 Simulasi Uji Fatigue Rasio Alur Pasak 3:3}

Dapat dilihat pada gambar 2, 3, dan 4 bahwa daerah yang mengalami kelelahan fatigue ditunjukkan oleh daerah yang berwarna merah yang terdapat pada radius fillet dari alur pasak. Semakin dalam alur pasak maka daerah fillet tersebut akan semakin berwarna merah, hal ini menunjukkan bahwa di daerah tersebut terjadi takik dan akan menimbulkan kerusakan saat digunakan sebagai poros.

Setelah melakukan simulasi uji fatigue maka selanjutnya akan didapatkan kurva S-N dari hasil pengujian. Kurva $\mathrm{S}-\mathrm{N}$ ini dibagi sesuai variannya.

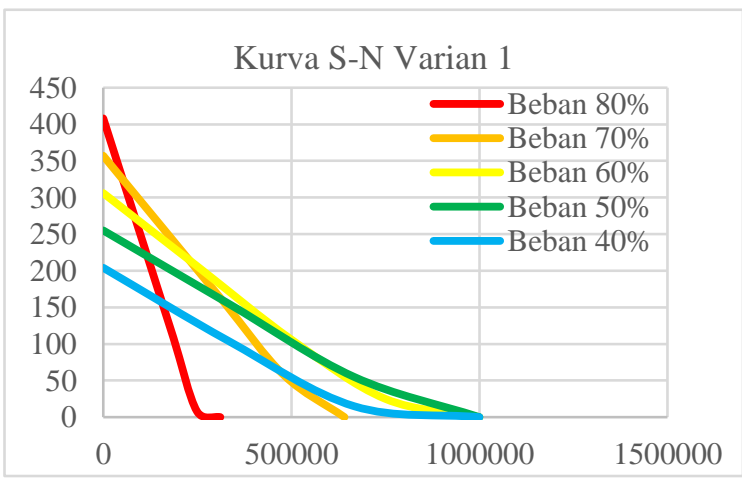

Gambar 5 Kurva S-N Varian 1

12 Fahmiansyah, Bachry., dkk; Pengaruh Rasio Geometri Alur Pasak Poros Terhadap Kegagalan Fatigue 


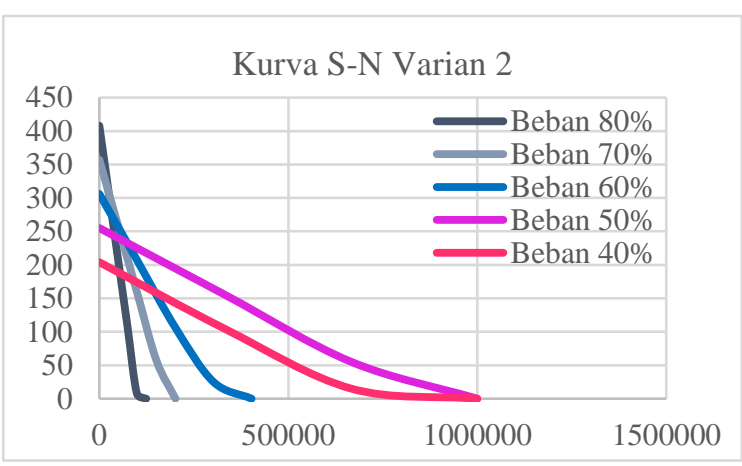

Gambar 6 Kurva S-N Varian 2

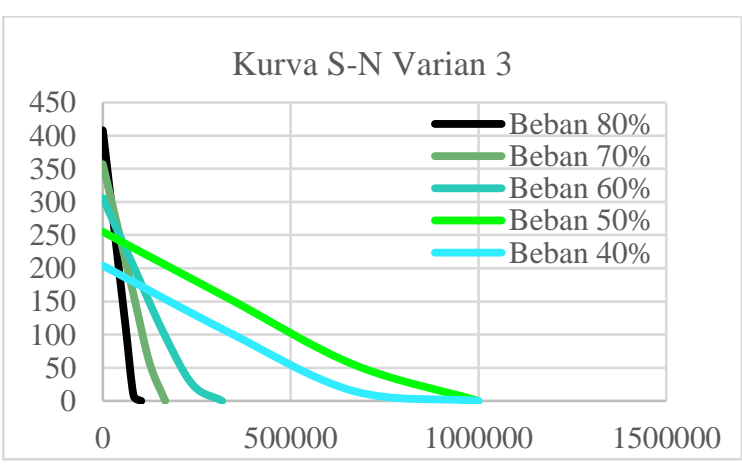

Gambar 7 Kurva S-N Varian 3

Kurva S-N ini menunjukkan sampai pada siklus ke berapa material mengalami kerusakan. Pada kurva S-N hasil simulasi dapat dilihat bahwa variasi rasio alur pasak yang paling kuat terhadap fatigue adalah rasio 3:1 pada pembebanan $70 \%$ menerima beban sebesar $357 \mathrm{MPa}$ mendapat siklus minimal 641.211 siklus. Pada variasi rasio alur pasak 3:2 material akan mengalami kerusakan pada pembebanan $60 \%$ dengan menerima beban sebesar $306 \mathrm{MPa}$ dan mendapat siklus minimal 402.699 siklus. Sedangkan nilai kekuatan fatigue terendah didapat pada variasi rasio alur pasak 3:3 pada pembebanan $60 \%$ menerima beban sebesar $306 \mathrm{MPa}$ mendapatkan siklus minimal 317.727 siklus. Jadi pada simulasi dengan variasi rasio alur pasak ini semakin besar rasio nya dan beban sudah melebihi $50 \%$ dari ultimate tensile strength material maka material tersebut terindikasi akan mengalami kerusakan akibat kegagalan fatigue.

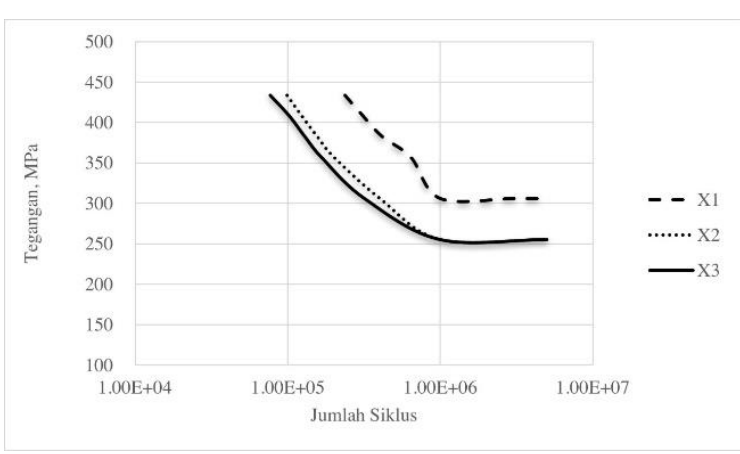

\section{Gambar 8 Kurva S-N Beban $80 \%$}

Grafik di atas menunjukkan perbedaan umur material pada pembebanan yang sama yaitu $80 \%$ dengan varian rasio alur pasak yang berbeda. Terlihat bahwa varian 3 atau X3 umurnya lebih pendek dibandingkan dengan varian 2 atau X2 dan varian 1 atau X1. Umur varian 1 bisa menjadi lebih panjang dikarenakan konsentrasi tegangan yang bekerja lebih sedikit dibandingkan varian 2 dan varian 3. Untuk perhitungan tegangan yang bekerja pada setiap varian adalah gaya yang bekerja dibagi dengan luas penampang yang terdampak. Untuk luas penampangnya adalah luas permukaan silinder bagian tengah dikurangi dengan luas permukaan dinding alur pasak. Untuk itu pada varian 1 didapatkan tegangan yang bekerja sebesar 1,28 MPa, varian 2 tegangan yang bekerja sebesar $1,41 \mathrm{MPa}$, sedangkan varian 3 tegangan yang bekerja sebesar 1,56 MPa. Dari hasil perhitungan tegangan ini dapat dilihat bahwa varian 1 tegangan yang bekerjanya nilainya paling kecil, oleh sebab itu untuk varian 1 umur fatigue nya akan lebih lama dibandingkan dengan varian 2 dan varian 3 .

\section{KESIMPULAN}

1. Kedalaman alur pasak sangat berpengaruh terhadap umur fatigue material. Semakin dalam alur pasak maka umur lelah material akan semakin pendek.

2. Rasio alur pasak yang lebih cepat mengalami kegagalan fatigue adalah 3:3 yaitu $3 \mathrm{~mm}$ lebar pasak dan $3 \mathrm{~mm}$ kedalaman pasak dengan pembebanan $80 \%$ sebesar $408 \quad \mathrm{MPa}$ mendapatkan siklus minimal 102.371 dan nilai safety factor 0,63 yang mana nilai safety factor di bawah 1 mengindikasikan akan terjadi kegagalan fatigue pada material sebelum mencapai 1.000.000 siklus. 


\section{DAFTAR PUSTAKA}

[1] Sunardi, R. Lusiani, and R. Santoso, "Effect of airflow speed as cooling media in the hardening process against hardness, corrosion rate and fatigue life of medium carbon steel," Bull. Mater. Sci, vol. xx, No. x, no. x, pp. 1-8, 2017, doi: $10.1007 / \mathrm{sxxxx}-0 \mathrm{xx}-1 \mathrm{xyz}-8$.

[2] S. Sunardi, E. Listijorini, and R. Sandro, "Pengaruh Bentuk Bukaan Terhadap Kekuatan dan Getaran Balok," Sintek J. Mesin Teknol., vol. 12, no. 2, pp. 107-112, 2018.

[3] Sunardi, E. Listijorini, and M. Sahroni, "Pengaruh Jarak Sel Bukaan Balok Terhadap Kekuatan Material dan Karakteristik Getaran," Mach.; J. Tek. Mesin, vol. 2, no. 2, pp. 6-10, 2016.

[4] M. Blatnická, M. Sága, P. Kopas, and M. Handrik, "Numerical simulation and experimental verification of torsion fatigue tests for material Weldox," Transp. Res. Procedia, vol. 40, pp. 631-638, 2019, doi: 10.1016/j.trpro.2019.07.090.

[5] E. Budiyanto, E. Nugroho, and A. Zainudin, "Uji Ketahanan Fatik Aluminium Scrap Hasil Remelting Piston Bekas Menggunakan Alat Uji Fatik Tipe Rotary Bending," Turbo J. Progr. Stud. Tek. Mesin, vol. 7, no. 1, 2018, doi: 10.24127/trb.v7i1.717.

[6] R. Rahmatullah and R. Ahmad, "Analisa Pengujian Lelah Material Bronze Dengan Menggunakan Rotary Bending Fatigue Machine," J. Rekayasa Mater. Manufaktur dan Energi, vol. 1, no. 1, pp. 1-11, 2018, doi: 10.30596/rmme.v1i1.2430.

[7] N. L. Pedersen, "Stress concentrations in keyways and optimization of keyway design," $J$.
Strain Anal. Eng. Des., vol. 45, no. 8, pp. $593-$ 604, 2010, doi: 10.1243/03093247JSA632.

[8] I. Isranuri, S. Abda, F. Ariani, D. T. Mesin, F. Teknik, and U. S. Utara, "Pengujian Fatik Pada Material Paduan Aluminium," no. 3, pp. 51-59, 2017.

[9] S. O. Afolabi, B. I. Oladapo, C. O. Ijagbemi, A. O. M. Adeoye, and J. F. Kayode, "Design and finite element analysis of a fatigue life prediction for safe and economical machine shaft," J. Mater. Res. Technol., vol. 8, no. 1, pp. 105-111, 2019, doi: 10.1016/j.jmrt.2017.10.007.

[10] S. S. H. A.-M. B. Engel, "Failure Analysis and Fatigue Life Estimation of a Shaft of a Rotary Draw Bending Machine," Int. Sch. Sci. Res. Innov., vol. 11, no. 11, pp. 1785-1790, 2017.

[11] M. T. Ozkan and F. Erdemir, "Determination of stress concentration factors for shafts under tension," Mater. Test., vol. 62, no. 4, pp. 413421, 2020, doi: 10.3139/120.111500.

[12] S. P. Raut and L. P. Raut, "A review of various methodologies used for shaft failure analysis," Int. J. Eng. Res. Gen. Sci., vol. 2, no. 2, pp. 159 171, 2014.

[13]B. Pratowo and N. Apriansyah, "Analisis Kekuatan Fatik Baja Karbon Rendah SC10 Dengan Tipe Rotary Bending," J. Tek. Mesin Univ. Bandar Lampung, vol. 2, no. 1, pp. 49-58, 2016.

[14]AzoM, "Stainless Steel - Grade 410 ( UNS S41000)," pp. 1-5, 2001.

[15] G. E. Dieter, Mechanical metallurgy. 2011.

[16] V. L. H. Vlack, Ilmu dan Teknologi Bahan (Ilmu Logam dan Bukan Logam). 1994.

[17] J. Marta, "Simulasi Pengujian Fatigue Pada Fork Racing Bicycle Menggunakan Standar Cen 14781,"2016.

14 Fahmiansyah, Bachry., dkk; Pengaruh Rasio Geometri Alur Pasak Poros Terhadap Kegagalan Fatigue 